\title{
Attitudes toward Women in Managerial Position in Pakistan: A Comparative Study
}

\author{
Uzma Ali, Ayesha Khan, and Seema Munaf
}

\begin{abstract}
This study was undertaken in order to investigate the difference in attitude towards women in managerial position between male and female employees. It is a comparative study in which 50 employees including 25 male and 25 female participated as a sample. The minimum educational qualification was graduation. After taking their consent they were individually requested to fill in the demographic data sheet, followed by Attitudes toward Women as Managers (ATWAM) Scale. For statistical analysis t'test was applied, which indicates that there is no significant difference between males and females in their attitude towards women managers in Pakistan. Supplementary findings reveal that males residing in joint families have significantly negative sex-role stereotypes towards women as managers whereas males residing in nuclear families possess a neutral attitude towards women as managers. Further males having working mothers as well has significant positive attitude towards woman managers as compared to males having mothers who are housewives.
\end{abstract}

Index Terms-Attitude, women, managers, employee, negative sex-role, stereotypes.

\section{INTRODUCTION}

Women's educational and professional life and their status in society are at present more on increase due to efficient and dedicated role played by them in different organizations. From junior staff up to managerial position which is not limited to educational management, they not only handle particular department but also as a political leaders they can represent their entire nation. Some women have now become more powerful, knowledgeable and function intelligently in crises situations, in the world of management. Nowadays they are ready to take challenges of the practical life and do not limit them to the domestic domain only. We can count number of woman playing significant role in our society. We can see how media highlights the contribution of women in different fields. Due to their extraordinary performance in various professions, now attitude towards women has changed in various countries. Particularly in job situation attitude towards woman as manager has now becoming positive in many countries because they are now showing their efficiency in many masculine related management positions. However sometimes we perceive that women limits their potentials to specific posts in the work setting, therefore others also perceive them as capable of handling

Manuscript received February 28, 2013; revised April 16, 2013.

The authors are with the Institute of Clinical Psychology, University of Karachi, 118 Block 20, Abul Asar Hafiz Jalindhri road, Gulistan-e-Jauhar, Karachi, Pakistan (e-mail: uzma_kamranali@yahoo.com, ayesha.k.mail@gmail.com,drseemamunah@hotmail.com). limited works at job.

Herbert and Yost (1978), [1] writing indicates that a number of people believe that women can disqualify for taking responsible position in masculine jobs. With this impression in mind in past years varieties of researches have been conducted throughout the world focusing on various psychosocial issues related to women. With rapid increase of women leaving and staying away from home for higher education and bread earning, raises questions in the mind of employers that "whether women can be hired for administrative post, other than educational management". With hiring of women on merit, equal opportunity, their gradual promotions in public sector organizations and non availability of males for appointment as head for particular fields made human resource management to look into possible appointment of highly qualified females to management posts. In spite of efficient performance and increase in finance, production and marketing of female owned /managed organization there remain a question in the mind of many employers that how women manager can overcome particular traits necessary and important condition for particular job. Now we can find in literature lots of researches related to attitude towards women in general as well as in job and at managerial position, of male and female students, professionals, colleagues etc. The results were both positive as well as negative.

In the writing of Guney, Gohar, Akinci, and Akinci (2006) [2] we come across the work of Dubno (1985) [3] and Papalexandris and Bourantas (1991), [4] who found that male MBA students had more negative attitude towards women managers than female students over the period 1975-1983 and there was no major change in their views in these eight years.

Similarly Willemsen (2002) [5] found that Netherland management students related more male traits as compared to female traits with successful manager

As mentioned in Welle and Heilma (n.d) [6] that Heilman (2001) [7] attribute gender discrimination in work setting to the "lack of fit model". Further Bielby and Baron (1986) [8] consider that in certain institutions there is high percentage of one particular sex. Similarly Lips (2003) [9], documents that one can observe more female nurses and male engineers as compared to male nurses and female engineers respectively. Hence there are certain jobs which require masculine traits, therefore dominated by males while those require female characteristics are dominated by females (Cejka \&Eagly, 1999) [10].

Earlier it was also revealed through research of Heilman, Martell and Simon, (1988) [11] that even when females are well qualified and are fit for certain management post still 
males are considered as fit for the same and it is believed that they would be able to execute that task more successfully than females. Welle and Heilma [6] also communicate that Davison and Burke (2000) [12] consider that in selection procedure of certain male type jobs, males are more in the favorable position than females. Moreover several women on senior position believe that "social exclusion" is one of the hindrances in promotion of females (Catalyst, 2004) [13].

Although a lot of apparent and non observable negative attitude towards women as a manager prevails still the numbers of women in managerial positions are increasing day by day and women are able to set themselves whether it is their own business or a hired managerial position. Women are functioning at these senior positions successfully.

On managerial posts one can see only 20-40\% in 2000-2002 in countries from where data was collected, which includes 48 out of 63 countries. Women's contribute to managerial position can be seen more in North America, South America and Eastern Europe as compared to East Asia, South Asia and the Middle East (ILO, 2009) [14].

In Muslim countries, Abdalla, (1996), [15].found that attitude towards women of Qatari and Kuwaiti professionals, college students and their parents was traditional. Moreover Mostafa (2005) [16] found that there was difference of attitude towards women manager among students of UAE and older people, as well as there was difference in view between males and females regarding the role and contribution of women in society.

As point out by Guney et al. [2] that, in Malaysia Koshal et al. (1998) [17] documented that at subordinate level women managers in Malaysia perceived the resistance from both gender for their progress. Later Sakalli and Beydogan (2002) [18] found that in Turkey also male college students has less positive attitude toward women managers as compared to females. Similarly the actual work of Guney et al. [2], shows that, for managerial position in Turkey both women and men expressed negative views. They further found that Pakistani males have a positive attitude towards women as a manager.

Hence the present research study aims to focus on the attitude of males and females towards women in managerial posts in Pakistan. Our interest is to find out whether there are any biases or negative sex role stereotypes in males or females towards women in high managerial posts in the professional fields or not. The purpose of the study therefore was to study the difference between males and females of attitudes about women in managerial posts in Pakistan. A comparison between their perceptions about women managers was made to gather in depth information about differences in attitudes.

Hypothesis

Attitude towards women in managerial position would be different of male and female employees.

\section{Methodology}

\section{A. Participants}

Sample includes 50 employees including 25 male and 25 female. Their age was between $25-45$ years with minimum educational qualification of graduation and job experience of not less than 05 years in that particular job. Data was collected only from those institutions and departments where women were manager/Administrator.

\section{B. Measures}

\section{1) Demographic information form}

It was used to collect information such as participant's name, date of birth, academic qualifications, occupation and name of organization where he/she is employed, current designation, year of experience at present job, marital status, family setup, and whether their mothers, wives or sisters were housewives or working women. Along with this an introduction to the participant and informed consent form was given which explained the purpose of the study as well as the consent of the participants was taken.

2) The attitudes toward women as managers (ATWAM) by Yost and Herbert (1998) [19]

This scale was used to measure the attitude towards women in managerial posts. It has 12 items, but only 10 items are scored. Each item can be marked on three statements. Participants are required to mark one statement as "M," indicative of most agreeable statement about self, and one statement as "L," indicative of least agreeable statement about self. The total score provides an indication of the respondent's feelings about women in managerial posts.

- Low ATWAM score ( below 30)= Positive about women managers

- Neutral ATWAM score (30-40) = Neither positive nor negative about women managers

- High ATWAM score $(40+)=$ Negative sex-role stereotypes

\section{3) Reliability/ Validity of ATWAM}

It is internally consistent, reliable scale. For example, its test-retest reliability was 0.766 , odd-even correlation was 0.8129 and first half-second half correlation was 0.9103 .

\section{Procedure}

The study was designed carefully with detailed research about the scale chosen and the literature review collected. After the design was selected, the participants were selected through convenient sampling with care to select only those participants whose minimum educational qualification was graduate and their current job experience was at least five years. Further the participants were requested for their voluntary participation and informed that they were free to withdraw from the study at any stage of the study. The questionnaire was then presented. Care was taken that no biases should contaminate the study. After the administration, the participants were thanked warmly for their participation in the study. Following the scoring, for statistical analysis t' test was applied.

\section{Ethical Considerations}

A good rapport was established with the participants to make them comfortable so that they can feel at ease. They were given opportunity to clarify any misconceptions that they held about taking part in the study. Questionnaires were administered only after complete consent was taken from the participants and information was given about what the research was, and how the data would be utilized. They were 
also informed that it is harmless research.

Only after their consent for voluntary participation the forms were given to them. They were given full right to withdraw at any stage of the study. They were assured that their personal information would remain confidential and data would be used for research purpose only.

\section{1) Operational definition of attitude toward women as manager}

In present research it is defined as employee's belief whether positive, neutral or negative sex-role stereotypes about women as manager or administrator.

\section{RESULTS}

\section{A. Descriptive Statistics (see Table I)}

TABLE I: DESCRIPTIVE STATISTICS OF ATTITUDE TOWARDS WOMEN AS MANAGER OF EMPLOYED MALES AND FEMALES ON VARIOUS VARIABLES $\begin{array}{lllll}\text { Groups } & \text { M N } & \text { SD } & \text { Range of Attitude }\end{array}$

\begin{tabular}{|c|c|c|c|c|}
\hline Males & 37.72 & 25 & 7.73 & Neutral \\
\hline Females & 34.16 & 25 & 6.76 & Neutral \\
\hline Total & 35.94 & 50 & 7.41 & Neutral \\
\hline $\begin{array}{l}\text { Unmarried } \\
\text { males }\end{array}$ & 38.88 & 16 & 8.21 & Neutral \\
\hline $\begin{array}{l}\text { Married } \\
\text { Males }\end{array}$ & 35.67 & 9 & 6.76 & Neutral \\
\hline $\begin{array}{l}\text { Unmarried } \\
\text { Females }\end{array}$ & 35.83 & 12 & 4.34 & Neutral \\
\hline $\begin{array}{l}\text { Married } \\
\text { Females } \\
\end{array}$ & $\frac{32.62}{35.94}$ & $\frac{13}{50}$ & $\frac{8.29}{7.41}$ & Neutral \\
\hline Total & 35.94 & 50 & 7.41 & Neutral \\
\hline $\begin{array}{l}\text { Males in } \\
\text { Nuclear } \\
\text { Families }\end{array}$ & 34.54 & 13 & 9.21 & Neutral \\
\hline $\begin{array}{l}\text { Males in } \\
\text { Joint } \\
\text { families }\end{array}$ & 41.17 & 12 & 3.61 & $\begin{array}{c}\text { Negative } \\
\text { sex-role stereotypes }\end{array}$ \\
\hline $\begin{array}{l}\text { Females in } \\
\text { Nuclear } \\
\text { Families }\end{array}$ & 34.94 & 17 & 5.61 & Neutral \\
\hline $\begin{array}{c}\text { Females } \\
\text { in Joint } \\
\text { families }\end{array}$ & 32.50 & 08 & 8.94 & Neutral \\
\hline Total & 35.94 & 50 & 7.41 & Neutral \\
\hline $\begin{array}{l}\text { Males havi } \\
\text { mothers as } \\
\text { housewife }\end{array}$ & $\begin{array}{l}\text { ng } \\
39.47\end{array}$ & 19 & 7.10 & Neutral \\
\hline $\begin{array}{l}\text { Males havi } \\
\text { working } \\
\text { mothers }\end{array}$ & 32.17 & 06 & 7.54 & Neutral \\
\hline $\begin{array}{l}\text { Females ha } \\
\text { mothers as } \\
\text { housewife }\end{array}$ & $\begin{array}{l}\text { ving } \\
34.05\end{array}$ & 19 & 5.19 & Neutral \\
\hline $\begin{array}{l}\text { Females ha } \\
\text { working } \\
\text { mothers }\end{array}$ & $\begin{array}{l}\text { ving } \\
34.50 \\
\end{array}$ & 06 & 11.05 & Neutral \\
\hline Total & 35.94 & 50 & 7.41 & Neutral \\
\hline
\end{tabular}

\section{B. Inferential Statistics}

\section{1) Main findings}

TABLE II: DIFFERENCE IN MEAN SCORES OF ATTITUDE TOWARDS WOMEN AS MANAGER BETWEEN EMPLOYED MALES AND FEMALE

\begin{tabular}{|c|c|c|c|c|c|c|}
\hline Groups & $\mathrm{N}$ & $M$ & SD & $\mathrm{t}$ & $\mathrm{df}$ & Sig. \\
\hline Males & 25 & 37.72 & 7.73 & \multirow{2}{*}{1.73} & \multirow{2}{*}{48} & \multirow{2}{*}{.090} \\
\hline Females & 25 & 34.16 & 6.76 & & & \\
\hline
\end{tabular}

Interpretation: It is obvious from Table II the difference in means that there is an insignificant difference of attitude towards women as managers between employed males and females, which indicate that both male and female employees have similar attitude towards women as managers.

\section{2) Supplementary findings (see Table III)}

TABLE III: DIFFERENCE IN MEAN SCORES OF ATTITUDE TOWARDS WOMEN AS MANAGER BETWEEN EMPLOYED MALES AND FEMALES ON DIFFERENT

\begin{tabular}{|c|c|c|c|c|c|c|}
\hline \multicolumn{7}{|c|}{ VARIABLES } \\
\hline Groups & $\mathrm{N}$ & M & & $\mathrm{t}$ & df & Sig. \\
\hline Unmarried & & & & & & \\
\hline Males & 16 & 38.88 & 8.21 & & & \\
\hline $\begin{array}{l}\text { Married } \\
\text { Males }\end{array}$ & 09 & 35.67 & 6.76 & .995 & 23 & .330 \\
\hline $\begin{array}{l}\text { Unmarried } \\
\text { females }\end{array}$ & 12 & 35.83 & 4.34 & & & \\
\hline $\begin{array}{l}\text { Married } \\
\text { Females }\end{array}$ & 13 & 32.62 & 8.29 & 1.200 & 23 & .243 \\
\hline $\begin{array}{l}\text { Males in } \\
\text { Nuclear } \\
\text { Families }\end{array}$ & 13 & 34.54 & 9.21 & & & \\
\hline $\begin{array}{l}\text { Males in } \\
\text { Joint } \\
\text { Families }\end{array}$ & 12 & 41.17 & 3.61 & -2.329 & 23 & .029 \\
\hline $\begin{array}{l}\text { Females in } \\
\text { nuclear } \\
\text { families }\end{array}$ & 17 & 34.94 & 5.61 & & & \\
\hline $\begin{array}{l}\text { Females in } \\
\text { Joint } \\
\text { Families }\end{array}$ & 08 & 32.50 & 8.94 & .837 & 23 & .411 \\
\hline $\begin{array}{l}\text { Males having } \\
\text { mothers as } \\
\text { housewife }\end{array}$ & 19 & 39.47 & 7.10 & & & \\
\hline $\begin{array}{l}\text { Males having } \\
\text { working } \\
\text { mothers }\end{array}$ & 06 & 32.17 & 7.54 & 2.166 & 23 & .041 \\
\hline $\begin{array}{l}\text { Females having } \\
\text { mothers as } \\
\text { housewife }\end{array}$ & 19 & 34.05 & 5.19 & & & \\
\hline $\begin{array}{l}\text { Females having } \\
\text { working } \\
\text { mothers }\end{array}$ & 06 & 34.50 & 11.05 & -.138 & 23 & .891 \\
\hline
\end{tabular}

Interpretation: It is obvious from mean differences that there is an insignificant difference of attitude towards women as managers between employed unmarried and married males, unmarried and married females, females in nuclear and joint families, and females having mothers as housewife and working mother. However, significant difference was noted between employed males residing in nuclear and joint families, which show that males residing in joint families have negative sex-role stereotypes attitude towards women as managers whereas males residing in nuclear families have neutral attitude towards women as managers. Moreover there was difference in ATWAM of those males whose mothers were housewives and those whose mothers were working women.

\section{DISCUSSION}

In this section focus would be on discussion with reference to our results, then conclusion, implication, limitation of the study and avenue for future research would be mentioned. In the end acknowledgment would be followed by references and short biography of the first author. 
As mentioned earlier our objective of the study was to determine gender difference in attitude towards women as managers in the organizations where women were the managers or administrators. Our formulated hypothesis was that "Attitude towards women in managerial position would be different of male and female employees". Results of the study clearly indicate that our hypothesis was not proved. It is clear from the Table II that both male and female employees do not differ in their attitude towards women as managers. Contrary to it, Saeed (2004) [20] as point out by Guney et al [2], consider that rights and status of Pakistani women are still limited as compared to males. In other countries also for example work of Eagly, Makhijani and Klonsky (1992) [21], as in Welle and Heilma [6] also reveals that females are assessed as less competent in manly characterized management jobs. As mentioned earlier, Davison and Burke (2000) [12] consider that in selection procedure of certain male type jobs males are in the favorable position than females. However our present result is not against women mangers. This gives us an idea about Pakistani employees that, they are more goals oriented and are least bothered by who is running the organization where they are working. They are ready to accept management of women in similar way as they accept the management of males. Guney et al. [2] document that in Pakistani culture employees don't usually criticize women manger as usually they are not appreciated to express negative view about the management whether it is male or female. They are more concern with their work.

In present study attitude towards women managers is neither positive nor negative. This may also be due to the fact that there is shift in the status of women in Pakistan in last two decades. In Pakistan stereotype women role is now taking different form and they are now becoming active in male dominant professions. In rural areas too they are working alongside with males (Lari, 2000 as in Guney et al.) [2], [22].

In Pakistan one can find that women have equal opportunity to attain higher post, because most of the companies select their employees on the bases of merit, responsibility, courage, and confidence. Here working women environment was further reinforced by female political leaders becoming members of the Parliament. In National Assembly, Provisional Assembly and in Senate we find various seats occupied by females. The first female Prime Minister of Muslim country was also from Pakistan. We can also find in educational management, women as school and college Principals, Chairpersons of various departments, Deans of different faculties as well as Vice Chancellors of Universities. We can see women running their own business such as commercial, educational as well as mental and physical health institutions.

In present research supplementary finding indicate that males have more negative sex-role stereotypes in joint families as compared to nuclear family set up. This may be attributed to the factor that in joint families, the responsibilities are distributed among various female members of the home. Hence women's individual characteristics of supervision of home remain unclear in joint families; therefore this can be the reason that in such environment, management of one particular woman is not identifiable. This perception of home management by many women in joint family and one women in nuclear family might have influence their perception of women as manager in the institutions where they are working. Thus it is clear that attitude of employees towards women as manager seems neutral on variables of gender, marital status and female having mother as housewife/working women, except men residing in joint family systems where it is obvious from their mean score that they have significant negative sex-role stereotypes. Further it is clear from table 3 that males having working mothers also has significant positive attitude towards woman managers as compared to males having mothers who are housewives. This may be attributed to their experience of working mother who is capable of managing home as well as the job responsibilities successfully.

\section{CONCLUSION}

The purpose of the research was to determine gender difference in attitude towards women as manager in Pakistan. From results we can conclude that in Pakistan women enjoy respectable position and both males and female employees has neutral attitude towards women in managerial position.

\section{A. Implications}

The results are of utmost importance as it is recommended that owners of public and private sectors can hire women in administrative position with fair degree of confidence as people of Pakistan do not seem to have negative attitude towards women as manager.

\section{B. Limitations of the Study and Avenue for Future Research}

Sample size of employed males and females was very less. Although results do depict true picture of attitude towards women as manager in Pakistani culture, however it would have been more appropriate if employees have been maximum in number and from majority of institutions where women are in administrative positions.

Multiple comparisons on variety of sub variables with large sample size could have given us more accurate results. It is therefore suggested that future researcher may take larger sample of employees from both genders in order to generalize the results with confidence.

\section{ACKNOWLEDGMENT}

Authors acknowledge cooperation of heads of various institutions and its employees who gave their consent for data collection.

\section{REFERENCES}

[1] T. T. Herbert and E. B. Yost, "Women as effective managers a strategic model for overcoming the barriers," Human Resource Management, vol. 7, no. 1, pp. 18-25. Spring 1978.

[2] S. Güney, R. Gohar, S. K. Akıncı, and M. M. Akınci, "Attitudes toward women managers in Turkey and Pakistan," Journal of International Women's Studies, vol. 8, no. 1, pp. 194-211, November 2006.

[3] P. Dubno, "Attitudes toward women executives: a longitudinal approach," Academy of Management Journal, vol. 28 no. 1, pp 235-239, 1985.

[4] N. Papalexandris and D. Bourantas, "Attitudes toward women as managers: the case of Greece," International Journal of Human Resource Management, vol. 2, no. 2, pp. 133-148, 1991. 
[5] T. M. Willemsen, "Gender Typing of the successful manager-A stereotype reconsidered," Sex Roles, vol. 46, no. 11/12, June 2002.

[6] B. Welle and M. E. Heilman, "Formal and informal discrimination against women at work: the role of gender stereotypes," working paper, Center for Public Leadership, pp. 23-40.

[7] M. E. Heilman, "Description and prescription: How gender stereotypes prevent women's ascent up the organizational Ladder," Journal of Social Issues, vol. 57, pp. 657-674, 2001.

[8] W. T. Bielby and J. N. Baron, "Men and women at work: Sex segregation and statistical discrimination," American Journal of Sociology, vol. 91, pp. 739-799, 1986.

[9] H. M. Lips, "The gender pay gap: concrete indicator of women's progress toward equality," Analyses of Social Issues and Public Policy, vol. 3, no. 1, pp. 87-109, 2003.

[10] M. A. Cejka and A. H. Eagly, "Gender-stereotypic images of occupations correspond to the sex-segregation of employment," Sex Roles, vol. 25, pp. 413-423, 1999.

[11] M. E. Heilman, R. F. Martell, and M. C. Simon, "The Vagaries of sex bias: Conditions regulating the undervaluation, equivaluation, and overvaluation of female job applicants," Organizational Behavior and Human Decision Processes, vol. 41, pp. 98-110, 1988.

[12] H. K. Davison and M. J. Burke, "Sex discrimination in simulated employment contexts: A Meta-analytic investigation," Journal of Vocational Behavior, vol. 56, pp. 225-248, 2000.

[13] P. R. Gerkovich, Women and Men in U.S. Corporate Leadership: Same Workplace Different Realities? New York: Catalyst, 2004

[14] International labor Organization. (2009). Guidelines on gender in employment police. Information Resource Book Geneva. [Online]. Available: http://www.ilo.org/stat/lang--en/index.htm

[15] I. A. Abdalla, "Attitudes towards women in the Arabian Gulf region," Women in Management Review, vol. 11, no. 1, pp. 29-39, 1996.

[16] M. M. Mostafa, "Attitudes towards women managers in the United Arab Emirates: The effects of patriarchy, age, and sex differences," Journal of Managerial Psychology, vol. 20, no. 6, pp. 522-540, 2005.

[17] M. Koshal, A. K. Gupta, and R. Koshal, "Women in management? A Malaysian perspective," Women in Management Review, vol. 13, no. 1, pp. 11-18, 1998.
[18] N. U. Sakalli and B. Beydogan, "Turkish college students' attitudes toward women managers: the effects of patriarchy, sexism, and gender differences," Journal of Psychology, vol. 136, no. 6, pp. 647-656, 2002.

[19] E. B. Yost and T. T. Herbert. (1998). Attitude towards women as Manager Scale. [Online]. Available: http://home.snu.edu / jsmith/library /body/v12.pdf

[20] R. R. Saeed, Women status in Pakistan under customs and values and the controversial hudood ordinance 1979, 2004.

[21] A. H. Eagly, M. G. Makhijani, and B. G. Klonsky, "Gender and the evaluation of leaders: A Meta-analysis," Psychological Bulletin, vol. 111, pp. 3-22, 1992.

[22] Z. Lari. (2000). Self-empowerment for Women with Disabilities in Pakistan. [Online]. Available: ww.isec2000.org.uk/abstracts/papers_1/lari_1.htm

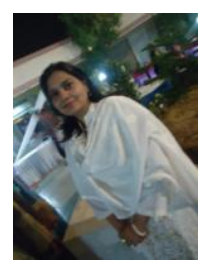

Uzma Ali is an associate professor at Institute of Clinical Psychology, University of Karachi, Pakistan. She was born at Lalamusa, Pakistan in 1971. She is being awarded her PhD degree in Clinical Psychology, from Institute of Clinical Psychology, University of Karach in 2003. She is working as teaching faculty and consultant clinical psychologist at the same Institute. Her main field of teaching is psycho diagnosis, psychotherapies, research method and Rehabilitation of Children with special needs. Presently she is also Rehabilitation In charge at the Institute. She does private practice for psychologically disturbed client, mainly depression, anxiety disorder, and marital problems. . She has many research publications in national and International Journal. She has produced three $\mathrm{PhD}$ in Clinical Psychology and currently supervising eight students. Mostly her focus of research in clinical psychology is related to childhood problems and disorders. She as well has few published papers related to organizational behavior. In addition she is an Associate editor of Pakistan Journal of Clinical Psychology.

Dr.Ali is a member of Pakistan Psychological Association and Pakistan Association of Clinical Psychology. 